\title{
SHIFTING THE BURDEN OF TAXATION FROM THE CORPORATE TO THE PERSONAL LEVEL AND GETTING THE CORPORATE TAX RATE DOWN TO 15 PERCENT
}

\author{
Harry Grubert and Rosanne Altshuler*
}

June 28, 2016

We consider three plans for shifting the tax on corporate income to the personal level to achieve a significant reduction in the corporate tax rate. One plan eliminates the corporate tax and taxes dividends and the annual change in the value of publicly traded financial assets at ordinary rates. The second integrates corporate and shareholder taxes. The third lowers the corporate tax rate to 15 percent and taxes dividends and capital gains as ordinary income. To prevent large reductions in capital gains realizations and dividend payouts, an interest charge on taxes deferred during the holding period would be imposed when an asset is sold. We conclude that the third alternative is more robust than the other two.

*Harry Grubert: Office of Tax Analysis, The U.S. Department of the Treasury, Washington, DC, USA (harry.grubert@treasury.gov),Rosanne Altshuler: Department of Economics, Rutgers University, New Brunswick, NJ, USA (altshule@rci.rutgers.edu). We are very grateful to Ralph Rector for tabulations of the U.S. Treasury tax files and to Siva Anantham, Gerald Auten, John Eiler, Emily Lin, and Jerry Tempalski for help with Office of Tax Analysis revenue and distributional tables. We thank Alan Auerbach, S. Douglas Borisky, Thomas Brennan, Patrick Driessen, Daniel Halperin, Michelle Hanlon, Jim Hines, Louis Kaplow, Edward Kleinbard, Rick Krever, Peter Merrill, Tim McDonald, John Samuels, Fadi Shaheen, Stephen Shay, Martin Sullivan and Alvin Warren for helpful conversations. We thank participants of the International Tax Policy Forum's Spring 2016 meeting and Harvard Law School's Tax Law, Policy and Practice seminar for useful comments. Nothing in this paper should be construed as reflecting the views and policy of the U.S. Treasury. 


\section{INTRODUCTION}

A high U.S. corporate tax rate is not sustainable as it creates strong incentives for income shifting and expatriation. Furthermore, the pressures on the high U.S. corporate rate continue to mount. For example, the United Kingdom corporate rate is scheduled to go down to 17 percent over the next five years. Many countries including the United Kingdom have introduced low tax “Patent Boxes” designed to attract research and development (R\&D) activity and intangible income. In response, similar schemes have elicited great interest in the United States. An example is the discussion draft for a 10 percent "Innovation Box" introduced on July 29, 2015 by Charles Boustany (R-LA) and Richard Neal (D-MA), members of the House Ways and Means Committee. These types of proposals are necessarily complex and susceptible to significant abuse because a special category of corporate income is singled out for very favorable tax treatment.

These competitive pressures will continue even with a "traditional tax reform" that broadens the corporate tax base to finance a lower statutory rate. This type of reform of the current system finances only a relatively modest reduction in the corporate tax rate. Even the ambitious reform plans introduced in the Senate and House in recent years do not go lower than 25 percent and they don’t appear to be fully revenue neutral.

Because of the limitations of base broadening and the compliance problems created by special subsidies for mobile income like patent boxes, several proposals have been presented for more dramatic reductions in the general corporate tax rate by shifting the burden of the tax on corporate income from the corporate to the individual shareholder level. These plans are intended to greatly reduce the benefits of income shifting and to equalize the advantages of foreign versus domestic corporate ownership and control. Indeed, as we will see, under some proposals, 
acquisitions of a U.S. corporation by a foreign corporation would be at a tax disadvantage compared to acquisitions by a domestic company.

For purposes of this discussion, we assume that proposals have to be revenue neutral and that the burden of the tax on corporate income should generally be held constant. For example, in the case of shareholder credits for corporate taxes paid, we assume the credits are financed by a higher individual tax on dividends. Of course, no single individual taxpayer is necessarily made whole, especially since the tax positions of different holders of U.S. shares vary greatly.

One set of proposals is exemplified by Toder and Viard (2014), who propose eliminating the corporate tax entirely and marking publicly traded financial assets to market every year with any gain along with dividends taxed as ordinary income. Nontraded corporations would be taxed as pass-throughs similar to partnerships. An important feature of the Toder-Viard proposal is that capital gains on nontraded assets are taxed on a realization basis at preferential rates as under current law.

Another way of shifting the burden of the corporate tax to the personal level is integration under which the shareholder pays a much higher tax on dividends but receives credits for taxes paid at the corporate level. This has recently been suggested by Graetz (2014) as a way to deal with inversions and income shifting. The proposal is modeled after the Australian "franking” system under which the corporation can distribute franked dividends that carry a credit for corporate level taxes. ${ }^{1}$ But credits can only be given for taxes paid to the Australian government, as there is no pass through of foreign taxes paid. Furthermore, franked dividends cannot be issued by the foreign owner of inverted or expatriated corporations even if the local operating company pays substantial Australian tax. Australian law prohibits "dividend streaming” in which

\footnotetext{
${ }^{1}$ The Australian tax system has significant differences from the U.S. system. In particular, pension funds are taxed and can therefore use shareholder credits.
} 
franked dividends are paid only to a certain class of taxpayers, but apparently companies can arrange their corporate structures to achieve the same result. We also look at a comprehensive integration plan proposed by the American Law Institute (ALI) under which the corporate tax is converted to a dividend withholding tax, in addition to other design changes, to see if it has an impact different from the Australian system.

We propose a third alternative that attempts to incorporate some of the desirable features of the other proposals without their shortcomings. It lowers the corporate tax rate to 15 percent, not zero. It finances this reduction by taxing all dividends and capital gains as ordinary income. By itself, this would lead to large behavioral responses. Taxpayers would defer the realization of capital gains. Dividend payouts would be reduced and the additional retentions converted into increases in stock values. Individuals would use corporations to accumulate passive income and recharacterize labor income as corporate income. To prevent these responses, when the asset is sold an interest charge is imposed on the deferred tax liabilities during the holding period. This tax treatment of realized gains is sometimes referred to as "retrospective taxation" and is related to the proposals by Vickrey (1939) and Auerbach (1991) for an interest charge to maintain neutrality between realizing a gain now versus continuing to hold the asset. However, our main focus is to prevent large behavioral responses — large reductions in capital gains realizations and dividend payouts compared to current law, the use of corporations to accumulate passive income, and tax avoidance in the form of labor income being disguised as corporate income. Unlike the mark-to-market proposal of Toder and Viard (2014), this alternative applies to the disposition of all assets, not just publicly traded financial assets, because tax is due only when the asset is sold.

There is a currently an interest charge regime in the Internal Revenue Code in the Passive Foreign Investment Company (PFIC) provisions. While the PFIC rules have some useful 
mechanics that we adopt, the interest charge regime we propose has several significant simplifications. These relate to the pattern of annual gains assumed when an asset is sold, the interest rate used, and the tax rate that applies to the annual gains.

Finally, the interest charge regime in our proposal requires two backstop rules to prevent the charge from being avoided. One is a deemed realization including interest charges at death to keep the tax from being deferred indefinitely. The other is a limit on dividends in any year with the excess subject to the capital gains regime. The purpose is to prevent a huge dividend shortly before a sale to escape the accumulated interest charges.

It is important to note that a shift in the burden of taxation from the corporate to the personal level is not a simple transfer from the U.S. corporate tax base to the U.S. shareholder owners of the tax base. As we will see, about 25 percent of the U.S. corporate tax base is owned by foreign direct and portfolio investors and at least another 25 percent is owned by pension funds, 401(k) plans, and other tax exempt institutions or saving plans. An increased personal level tax on dividends and capital gains will not apply to them. On the other hand, the increased tax on dividends and capital gains paid by U.S. taxable individuals will in part fall on income earned abroad by U.S. companies and U.S. portfolio investors. The alternative proposals all have to address the various problems presented by this incomplete transition from the U.S. corporate income tax base to the income of taxpayers subject to the U.S. personal income tax.

For simplicity, in what follows we refer to our plan for lowering the corporate rate to 15 percent, increasing the tax rates on dividends and capital gains to ordinary rates and imposing an interest charge upon realization on individual tax liabilities deferred during the holding period as the "interest charge" proposal. We conclude that the interest charge proposal has advantages over the other two approaches. The Australian type of "dividend franking” system is ineffective in 
discouraging income shifting. At least 50 percent of the shareholders are not subject to personal taxes on dividends and are not affected by any potential denial of shareholder credits. Furthermore, about half of U.S. multinational (MNC) companies pay enough U.S. tax to grant full franking credits to their shareholders. They can continue to engage in the income shifting they do now. Furthermore, even for the companies who do not pay sufficient U.S. tax to finance enough shareholder credits, companies and shareholders can respond in order to weaken the impact of the rule. Companies can cut back on their dividends, letting shareholders take out more of their return in the form of lightly taxed capital gains. Taxable shareholders can sell their shares with insufficient credits to tax exempts in exchange for shares in companies with full credits.

Finally, it is true that the potential loss in credits may discourage inversions. But there are many tax exempt shareholders who would welcome the benefits of inversion. They can acquire shares from the relatively few shareholders disadvantaged. Also, there are many major companies that pay little or no dividends. In summary, dividends are too elastic to use as a vehicle for controlling cross-border transactions.

The interest charge proposal has almost all the benefits of the mark-to-market plan without several of its serious shortcomings. One disadvantage of the latter plan is the large differential between the tax on traded asset capital gains and the tax on non-traded asset gains. The latter continue to enjoy the opportunity for deferring the realization of gains and also the current law preferential rate on these gains when they are finally realized. Another problem is the difficulty in achieving revenue neutrality with complete elimination of the corporate tax. Moreover, eliminating the corporate tax will not eliminate problems of income measurement as long as the rest of the world still taxes corporate income. 
The remainder of the paper is organized as follows. The second section presents information regarding the ownership of the corporate income tax base. This is important to understanding both the revenue and behavioral consequences of the different proposals that would shift the burden of the tax on corporate income from corporations to individual shareholders. We evaluate the Toder-Viard mark-to-market plan in the third section, and consider integration proposals, both in the form of shareholder credits with dividend taxation or by converting the corporate tax to a dividend withholding tax, in the fourth section. We discuss our interest charge proposal (taxing corporate income at a 15 percent rate and dividends and capital gains as ordinary income with an interest charge on deferred liabilities) in the fifth section. We consider design issues, incentives to defer capital gains compared to current law, transition issues, revenue consequences, effectiveness in combating income shifting and inversions, other possible behavioral responses, and distributional properties. In the final section we offer some conclusions regarding the relative attractiveness of the three different proposals to move the burden of the tax on corporate income to the personal level.

\section{OWNERSHIP OF THE U.S. CORPORATE TAX BASE}

In examining the shift of the tax on corporate income from the corporate to the personal level, it is important to identify the recipients of corporate income in order to understand the revenue and behavioral consequences of the reform. Are corporate shareholders taxable individuals, foreign shareholders, pension funds, or other types of tax exempts? Furthermore, the relevant answer depends on the proposal under consideration. If the reform is an integration plan with shareholder credits limited to U.S. taxes paid, the key factor is the share of U.S. corporate income owned by taxable resident individuals. If individual taxes on capital gains and dividends 
are increased, the relevant tax base should include income from individual holdings of foreign shares.

We review several estimates and supplement them with more recent information. Researchers have used several data sources. Auerbach (2006) and Rosenthal and Austin (2016) use the Federal Reserve Board Flow of Funds (FOF) data on the holdings of U.S. equities. Tax data can also be used to identify the holdings of 501(c)(3) organizations (tax exempts) and U.S. corporate taxes paid by foreign-controlled U.S. corporations. The data sources are somewhat different conceptually, as the value of holdings in the FOF data is different from that in the taxbased data. For example a U.S. corporation may have valuable stock but little U.S. taxable income because most of its worldwide income is abroad.

In spite of the different sources and methodologies, the studies all come to a similar conclusion — that at most 50 percent, and probably much less, of U.S. equities are held by taxable U.S. individuals. As we will see, this is significant for evaluating the proposals studied. For example, a reduction in the U.S. corporate tax rate coupled with an increase in personal level taxes can potentially lose a great deal of revenue because foreign and tax exempt shareholders gain from the corporate rate cut but are not affected by the personal level tax increase on dividends and capital gains.

Auerbach (2006), using FOF data, reports that households owned 42 percent of the market value of domestic companies. But he listed mutual funds separately and did not attempt to trace the share of their assets that was held in taxable accounts. Rosenthal and Austin (2016) estimate both direct and indirect holdings of U.S. corporate stock. They calculate the amounts held by nonprofits, in IRAs, and by both defined benefit and defined contribution pension funds. They conclude that in 2014 taxable household accounts only held 24 percent of U.S. corporate 
stock. This would be relevant for integration type plans where shareholder credits depend on U.S. corporate taxes paid. It is also useful in determining who benefits from a cut in U.S. corporate taxes. However, for proposals that include an increased tax on capital gains and dividends it would also be necessary to add U.S. resident holdings of foreign shares. Combining Bureau of Economic Analysis and Treasury data suggests that individual holdings of foreign shares are about 25 percent of their holding of U.S. shares. ${ }^{2}$

The estimates based on the FOF do not directly indicate who owns the U.S. corporate tax base. There is the problem of firm valuation versus tax paid to the U.S. Treasury referred to earlier. Furthermore, the FOF data do not seem to include investments by foreign-controlled companies in the United States and the taxes they pay. Internal Revenue Service (IRS) data indicate that, in 2012, foreign-controlled U.S. corporations paid 16.9 percent of total corporate taxes paid after credits (Hobbs, 2015). Tax based data on portfolio investment are not available, but Bureau of Economic Analysis data on the U.S. international position indicate that portfolio investment is greater than direct investment. That suggests that foreigners own at least 25 percent of the U.S corporate tax base.

Finally, Gravelle and Marples (2015) compare dividends received by individuals reported by the IRS Statistics of Income with dividends paid in the National Income and Product Accounts. They conclude that only about 25 percent of dividends appear on personal returns, consistent with the Rosenthal and Austin (2016) estimate that 24 percent of U.S. corporate stock is held by taxable individuals.

\section{ACCRUAL OR MARK-TO-MARKET TAXATION OF PUBLICLY TRADED FINANCIAL ASSETS}

\footnotetext{
${ }^{2}$ Refer to http://www.bea.gov/international/index.htm\#iip for more information.
} 
Toder and Viard (2014) have proposed eliminating the corporate tax entirely and substituting the inclusion in the annual personal tax base of dividends, interest, and the change in the value of publicly traded financial assets, all taxed as ordinary income. Assets would have to be marked to market each year. Capital gains on assets not publicly traded would be taxed as under current law, that is, upon realization at much lower rates. Publicly traded foreign stocks held by U.S. residents would also be marked to market.

A zero corporate tax rate would certainly eliminate all corporate gains from shifting U.S. income abroad or expatriating. There would be no benefit to shifting or expatriating, and any attempt to do so would risk being liable for positive foreign taxes. The plan also appears to simplify the tax system because companies would not have to compute U.S. taxable income under the Toder-Viard plan.

But the Toder-Viard approach has some serious shortcomings. One is the large revenue shortfall due to the fact that the personal tax base differs greatly from the corporate tax base. As discussed in the prior section, less than half the U.S. corporate tax base is owned by taxable U.S. individual taxpayers subject to current taxation on their investment income. The remainder is owned by foreign investors, pension funds, 401(k) plans, IRAs, and 501(c)(3) institutions (nonprofits) such as foundations and university endowments. Foreign investors are subject to only modest withholding taxes on dividends and are not subject to U.S. taxation of capital gains. Pension funds and retirement accounts are not currently taxed on corporate income and distributions to beneficiaries are already taxed as ordinary income.

Another major problem is the large tax differential between traded and nontraded financial assets. Owners of shares in companies not publicly traded would have two major advantages. They would retain the opportunity to defer realizing capital gains and, when they 
finally sell their shares, the gains would be taxed at a much lower rate. As a result, any assets in which expected capital gains are an important component of the total expected return would tend to shift to the nontraded sector. For example, Initial Public Offerings (IPOs) would be delayed, and many more companies would be taken private.

Toder and Viard (2014) recognize the problem of derivatives such as swaps on traded securities, and propose that they also be marked to market. The derivative may not be traded, however, which would require some valuation methodology. Some derivatives may be very complex involving interest rates and exchange rates as well as various types of securities. There would also be many line drawing issues on what constitutes a traded security. Many corporate bonds and preferred stocks are very thinly traded.

Furthermore the complete elimination of the corporate level tax amounts to a failure to exploit the market power of the United States in offering investments to foreigners. The optimal tax on foreign investment strikes a balance between the net marginal revenue collected and the benefits of additional capital in increasing the marginal product of workers. It is unlikely to be close to zero for a large country with unique intangibles like the United States.

Finally, it is unrealistic to believe that corporate taxable income would not have to be computed. Such a belief ignores the international environment that is the main motivation for the accrual proposal. Foreign countries will try to steal the U.S. tax base. For example, some major countries are of the opinion that all the income from the local sales by U.S. MNCs, including the return from U.S.-developed intangibles, belongs to them. There have to be international rules governing the division of income such as the Arms' Length Principle. If there is a transfer pricing dispute between countries under current law and there is a tax treaty, the respective 
revenue authorities enter into negotiation. If there is no corporate tax and no estimate of taxable income, how is the interest of the United States to be defended?

Toder and Viard (2016) have now revised their proposal. To get closer to revenue neutrality, they only cut the corporate rate to 15 percent. They also add shareholder integration and a tax on interest received by pension funds and tax exempts. Shareholder integration is discussed below.

\section{SHAREHOLDER CREDITS WITH DIVIDENDS}

One suggestion to discourage income shifting and expatriation is to provide credits to shareholders for U.S. taxes paid when they receive a dividend (Graetz, 2014; Graetz and Warren, 2014). U.S. companies could distribute "franked" dividends carrying the shareholder credit to the extent that the corporate income financing the dividend was fully subject to U.S. tax. The proposed system is modeled after the Australian franking system in which only taxes paid to the Australian Treasury are eligible for credits. There is no pass through of taxes paid to foreign governments.

Furthermore, no franking credits can be issued by foreign companies even if they have Australian subsidiaries paying Australian tax. Australian law does not permit dividend “streaming” under which some shareholders receive franked dividend and others do not. Apparently, however, corporations can achieve the equivalent of streaming by restructuring into separate divisions, each with their own shares. ${ }^{3}$

Because shareholder credits will be expensive in terms of lost revenues, we assume that there will be a substantial increase in the tax on dividends, consistent with the goal of largely

\footnotetext{
${ }^{3}$ There would also have to be minimum holding periods to claim the credit. Otherwise a tax exempt institution could sell the stock to a taxable entity just before the dividend payment date.
} 
maintaining the tax on corporate income. This means that shareholders that receive dividends not eligible for credits will have to pay much higher taxes.

If a company chooses to pay out all of its income, including foreign income, as dividends, and all of its shareholders are taxable resident individuals, it would have no reason to shift income or expatriate under an integration system with shareholder credits for corporate level taxes. Any reduction in U.S. tax would just be offset by lower shareholder credits. However, any departure from this extreme case would bring back the benefits of income shifting and expatriation. The opposite extreme is a company that never pays dividends while shareholders just infrequently sell part of their holdings and realize capital gains attributable, at least in part, to the retained earnings. Also, unlike in the mark-to-market proposal, the capital gains tax rate would have to remain substantially below normal personal rates to avoid large declines in realizations. For these shareholders, the benefits of income shifting and expatriation would remain the same as under current law.

In addition, as discussed earlier, more than 50 percent of the U.S. corporate tax base is owned by shareholders not currently subject to U.S. personal income taxation. These include foreign direct and portfolio investors, pension funds including IRAs and 401(k)s, and other tax exempts like 501(c)(3) institutions. They suffer no loss from receiving unfranked dividends and continue to benefit from income shifting and expatriations. This large group of shareholders, which is not affected directly by the franking scheme, creates the possibility of large clientele effects. For example, they could concentrate on companies that engage in a large degree of income shifting, while taxable individuals concentrate on companies with large domestic tax bases. Those not subject to the U.S. personal tax could continue to receive the dividends they 
receive now with no added tax liability. Taxable individuals might also shift into any type of company that is currently a low dividend payer.

The presence of a very large group of actual and potential shareholders not subject to personal U.S. taxes also has important implications for stock prices, as shares of companies with few available credits because of income shifting will not sell at a discount due to any tax that personal shareholders will have to pay on possible future dividends. If a company that pays few U.S. taxes retains all of its income, the eventual taxable seller will be able to readily sell his shares to a nontaxable investor at virtually the same price as under current law. Even a taxable buyer would be willing to pay for the full value of the company's assets including retained earnings because they would get a new basis at that value. The capital gain would be taxed at the current low tax rate.

\section{A. How Many MNCs Have Paid Enough U.S. Taxes to Provide Full Credits for Their Current Level of Dividends?}

In order to further explore the incentives facing companies and individual taxpayers under shareholder credit plans, we looked at how many U.S. multinational companies paid enough U.S tax to give full credits for the dividends they distributed to their shareholders. Corporate Form 1120 returns were used to identify the amount of U.S. tax a MNC paid in 2012. The tax returns were then linked to the company's financial data on COMPUSTAT to determine the amount of dividends paid in 2012. ${ }^{4}$

We then computed the maximum amount of dividends with full credits for corporate level tax that the company could distribute. If the amount of taxes paid is $T$ and we assume that

\footnotetext{
${ }^{4}$ Linking COMPUSTAT with data from tax returns is not straightforward and may result in an underestimate of the amount of U.S. tax paid relative to dividends paid in COMPUSTAT. Consolidation rules are easier in financial accounting. It is more likely that we missed taxes on an unconsolidated tax return than dividends by an unconsolidated financial affiliate.
} 
the U.S. corporate rate remains at 35 percent, the maximum amount of franked dividends is $T(1-0.35) / 0.35$. Note that $T / 0.35$ is pre-tax U.S. taxable income. Shareholders can receive the after-tax amount as dividends. For each 65 cents of dividends, the taxpayer would get a 35 cent credit which would first be added to income and then claimed as a credit against the final tax liability. This maximum amount of franked dividends that companies could pay was then compared to the amount they actually paid.

We found that companies with about half of MNC worldwide income paid dividends less than the maximum they could have, and about half paid more dividends than the maximum allowable amount. Therefore, the former group could continue to engage in and benefit from the income shifting they do now while also continuing to maintain their current level of dividends, Consider the group of companies that pay more dividends than they can frank with the U.S. taxes they pay. Individual shareholders will have to pay very high tax rates on their unfranked dividends if the plan is revenue neutral. ${ }^{5}$ Companies and shareholders can respond in several ways. For example, companies could reduce income shifting. The net benefit to the company and its shareholders would be the saving of marginal shifting costs plus any foreign tax that had been paid on the income. For each dollar less abroad, U.S. taxable income increases by more than a dollar because of the lower shifting costs. If a dollar of less income abroad that had paid zero tax simply became a dollar of U.S. taxable income with potential credits, there would be no benefit to the company. (Initially companies had equated marginal shifting costs with the tax differential.) As shifting is reduced further, the benefit declines as marginal shifting costs decline.

\footnotetext{
${ }^{5}$ The lack of sufficient credits can be handled in different ways. We assume that each shareholder will receive a certain percentage of unfranked dividends.
} 
But the company can also respond by paying fewer dividends. This saves the increased tax that shareholders would have to pay on dividends without full credits. We assume that initially the company has optimized the choice between current dividends and future capital gains based on tax costs and shareholder preferences. The higher cost of dividends relative to capital gains will disrupt this balance. But as dividends continue to be reduced, there will be a cost in terms of a large departure from shareholder preferences.

Shareholders can also respond by shifting some of their holdings to the first group of companies, those with dividends less than the maximum allowable amount. They could trade with foreign or tax exempt shareholders who are not affected by the personal tax on dividends. If the stocks are relatively substitutable, there will not be much change in relative prices between the two groups of companies. But the switch becomes less beneficial as shareholders depart further from optimal diversification and their preferred stock positions. This suggests that there will be an internal solution with adjustments along all three margins — reduced dividends, less income shifting, and a switch in shareholder portfolios.

Summing up, an integration scheme that restricts shareholder credits to taxes paid to the United States is an ineffective instrument for addressing income shifting. Only a relatively small amount of shareholders benefit from less income shifting, but they can also benefit from lower dividend payouts and a switch to companies that have room to increase dividend payouts that carry full credits. Moreover, we have not even considered other possible reactions such as MNCs with little U.S. taxable income acquiring domestic companies with a large stock of potential shareholder credits.

If companies can stream franked and unfranked dividends to different types of shareholders using different types of stock, for example, integration is even less effective in 
reducing income shifting. Taxable shareholders will concentrate on the shares with the franked dividends. The potential credits can be assigned to them and it is therefore more likely that they can receive full credits with their dividends. All types of shareholders can be content with the current level of shifting.

\section{B. Expatriations}

If we return to the no streaming assumption, the integration proposal is more effective against expatriations than income shifting because all dividend recipients subject to the U.S. personal income tax will be affected. Any tax paid by the U.S. operation that is now owned by a foreign company can no longer be used to provide a dividend credit. Any dividends paid by the U.S. operating company would go first to the new foreign owner. The increase in the dividend tax before credits under the system would make the U.S. taxable shareholders substantially worse off.

Of course, companies and shareholders could respond to lessen the impact. Companies could reduce their payout rates and let shareholders earn more of their return in the form of accruing capital gains. These gains when realized would be subject to the still low capital gains tax rate. Indeed, the U.S. corporations that pay little or no dividends would continue to be candidates for inversion. (If the foreign company eventually starts to pay dividends as it matures, the shares could be transferred to U.S. tax exempts or pension funds.) Another possibility is that U.S. taxable shareholders realize the increase in the stock price attributable to the inversion tax saving by selling to foreign shareholders or tax exempts. ${ }^{6}$ As suggested earlier, because of the large number of actual and potential holders of the stock not subject to the personal U.S. tax, the

\footnotetext{
${ }^{6}$ We assume that there would be rules restricting taxable shareholders from engaging in a swap with a tax exempt that turns dividends into capital gains. There is a new provision in Section 871(m) subjecting dividend equivalent payments to foreigners to withholding taxes. Some cases may be difficult to enforce. An example would be a stock forward where the expected dividend is buried in the price of the forward.
} 
price can be expected to reflect the full inversion gain with only a modest discount for the increased dividend taxes if held by a taxable U.S. person.

Beyond that, the loss of dividend credits as a result of a foreign acquisition may in some cases be contrary to the national interest. It may discourage a foreign acquirer that is a much more efficient user of the U.S. assets. The foreign-owned U.S. operation could end up paying more U.S. corporate taxes than it would in U.S. hands. But U.S. shareholders would prefer a less efficient U.S. acquirer. ${ }^{7}$

Finally, if different shares and streaming are possible, the impact of the integration proposal on inversion is much weaker. Taxable shareholders would receive dividends directly from the foreign-owned entity in the United States. Taxes paid to the U.S. Treasury could still be used to provide franked dividends. The incentives would remain much like the shifting incentives before the inversion. The analysis would only differ from the earlier shifting discussion if inversion reduced the cost of income shifting from the United States. The new foreign parent might be in a better position to strip income from the United States. That would be true in the case of interest stripping from the United States if no new interest stripping rules in Section 163(j) are enacted. Furthermore the foreign parent could shift income to low tax entities without being subject to the U.S. CFC rules.

\section{Foreign investment by U.S. MNCs}

Denying shareholder credits for foreign taxes will have a large negative effect on outbound investment. It is the equivalent of achieving National Neutrality under a worldwide system where there is only a deduction for foreign tax, not a credit. This will particularly affect

\footnotetext{
${ }^{7}$ To be sure, the surviving merged company could be a U.S. corporation to preserve the credits. There may be tax or nontax reasons why that is not chosen. The foreign acquirer may not wish to subject existing operations to the U.S. CFC rules and a worldwide tax system. A successful foreign acquirer would have an incentive to shift additional income to reduce the U.S. tax that can no longer be used as credits.
} 
investment in relatively high tax countries. Consider the case of a foreign investment producing 100 in pretax income where there is also a domestic investment yielding 100. The tax rate in each country is 30 percent. The dividend tax rate is 50 percent before eligible shareholder credits. The foreign investment has after-tax income abroad of 70 . When the 70 is distributed to U.S. shareholders, they have 35 remaining after the 50 percent tax with no credits. The domestic investment also has an after corporate tax income of 70 . When this is distributed to shareholders, they receive a credit of 30 from the government to offset the corporate level tax. They gross up their income to 100 and pay 50 percent of it. Their after-tax income is 50 .

Note that this is not the result in a dividend exemption regime combined with a classical dividend system. The 70 of foreign income would not be taxed at the corporate level in the United States. When the 70 is distributed to shareholders it would be subject to the same personal tax as the 70 of domestic dividends.

\section{The ALI Integration Proposal: Is it Fundamentally Different?}

Another integration variant was proposed in a report for the American Law Institute (ALI) by Warren (1993). Instead of shareholder credits based on franked dividends, the ALI proposal would convert the corporate tax to a dividend withholding tax (DWT) which can be used by the shareholder as a refundable credit. A dividend (grossed up) would be deductible from corporate taxable income with a withholding tax equal to the corporate tax rate. Any corporate tax paid by the corporation before the distribution, in a Taxes Paid Account (TPA), could be used as credits against the withholding tax. Thus if the corporation had not paid any U.S. tax, it would be liable for the dividend withholding tax. At the same time, the shareholder can credit the withholding tax against its personal liability. A single level of tax is the result. ${ }^{8}$

\footnotetext{
${ }^{8}$ Both integration versions assume that fully taxed income is distributed first when dividends are paid.
} 
The ALI proposal is very comprehensive with features designed to reduce tax planning opportunities. The DWT would be set at the highest individual tax rate in the year of distribution, which would also be the corporate tax rate. Furthermore capital gains would be taxable as ordinary income. ${ }^{9}$ The ALI would also impose a tax on dividends and capital gains earned by pension funds, tax exempts, and foreigners, with the same withholding tax credits available to domestic taxable shareholders. Taxing all capital gains at ordinary rates is necessary because capital gains would otherwise be a way of realizing the value of accumulated earnings without the need for TPA credits.

The Australian and ALI systems differ in who bears the direct burden of inadequate credits. For example, the dividend deduction scheme affects foreign investors and tax exempts differently from shareholder credits even if they are not taxed. If a company shifts income and therefore can only issue unfranked dividends, the tax exempts are indifferent because they are not taxable. They still receive corporate income free of any tax. On the other hand, under the ALI proposal, if the company pays a dividend it would be liable for the withholding tax on dividends because it would have insufficient TPA to use as credits. The tax exempt would no longer receive corporate income in the form of dividends free from tax at any level. (We assume that the company cannot have different types of stock with dividends going only to one type.)

However, that just means that tax exempts and foreigners would have a strong preference for capital gains if they continue to be untaxed. In addition, the tabulations cited above indicated that companies earning about half of MNC income would have enough TPA to credit the withholding tax on their current level of dividends. Their income shifting would not be restrained. Beyond that, the importance of tax exempts and foreigners as shareholders would cause U.S. companies to limit their dividends.

\footnotetext{
${ }^{9}$ The report does not specify whether this applies to all capital gains or just corporate shares.
} 
The ALI report explains the importance of taxing capital gains earned by foreign investors and tax exempts in the case in which the U.S. corporation has adequate potential credits in its TPA. The foreign investor could sell the stock to a domestic investor at a price that reflects the full value of the TPA. The domestic investor could use the TPA to shield any dividends and in addition would have a high basis in the stock that could be used in a realization. The income would be completely free of tax. Similarly, if the company shifts income and has no TPA to distribute, the tax exempt shareholder could realize the full value of the retained earnings by selling. Even a taxable individual who bought the shares would be willing to pay the full price of the company's assets. From the buyer's point of view, the purchase would be like a de novo investment.

The taxes on tax exempts and foreign shareholders would reduce some of the clientele effects in the Australian shareholder credit system, but they would constitute major changes in the U.S. tax system, particularly in the taxation of capital gains. ${ }^{10}$ The ALI report recognizes the administrative problems in attempting to tax capital gains earned by foreign shareholders. It suggests the possible use of the procedures in the Foreign Investment in Real Property Tax Act (FIRPTA), the only instance in which capital gains realized by nonresident foreigners are taxed by the United States. Under the FIRPTA rules the buyer has to withhold 15 percent of the gross sales value of the property interest. But the foreign seller has the opportunity to reduce the tax by filing a U.S. return showing the actual net gain and paying tax subject to normal progressive rates. Given the amount of portfolio investment in the U.S. shares, millions of foreign shareholders would have to file a U.S. return. FIRPTA in fact recognizes the problem by excluding publicly traded shares from the withholding requirements for holdings of 5 percent (10

\footnotetext{
${ }^{10}$ Dividends would not result in any net tax because any liability would be offset by credits. The shareholder gets a credit even if there is no TPA.
} 
percent for REITS) or less of the property company. (Incidentally, the ALI proposal does not seem to explicitly address the taxation of foreign shares held by domestic portfolio investors. This would include shares in inverted companies.)

Other aspects of the ALI proposal may create problems. One is the high corporate rate, suggested to be equal to the top personal rate, which would make it greater than 40 percent if the current schedule applies. A growing company that prefers reinvesting earnings to continually raising equity would potentially be taxed at a very high rate. It may have a greater incentive to shift income than under current law. (The Constructive Dividend proposal discussed below could offset that problem but, as we will see, that may create other opportunities for income shifting companies and their shareholders.)

Taxing capital gains as ordinary income will also cause problems because of a large reform-induced reduction in realizations (the response the interest charge proposal is designed to prevent). The data cited below on revenue sources indicates that the U.S. Treasury receives much more revenue from capital gains than dividends. This would affect the ability of achieving the goal of revenue neutrality under each alternative. (Revenue neutrality was not an explicit requirement of the original ALI report.) If extra revenue from capital gains does not arise, the top personal rate would have to be very high. Two levels of tax are being converted to one level, so the top personal rate would have to be the sum of the current tax at both the corporate and personal levels. In fact, it would have to be somewhat greater, because at any given top rate the withholding tax and credit loses revenue because shareholders below the top rate would receive refunds.

Finally, even for taxable individuals, the strategy of income shifting combined with retention and eventual realization still dominates a strategy of no income shifting with annual 
dividends and credits for U.S. taxes paid. For example, if the worldwide pre-tax return is 5 percent, and the personal and corporate tax rates are both 40 percent as in the ALI proposal, the shifting plus retention and eventual sale alternative results in a 25 percent greater increase in wealth after 20 years. The difference would obviously be greater if there is a capital gains preference. The ALI proposals would permit a corporation to pay a constructive dividend, instead of a cash dividend, with a basis adjustment for the shareholder. A corporation could therefore make a constructive dividend up to its Taxes Paid Account, so that shareholders selling their shares after a period in which the company retained shifted income would not have to sacrifice credits for U.S. taxes that were actually paid.

The various integration proposals were originally designed to address the double taxation of corporate distributions, not the problems of income shifting, inversions, patent boxes, and international tax competition. Indeed, the discussion in the ALI report of income that has not borne corporate tax only refers to tax preferences and whether they should be passed through to the shareholder. Attempting to reduce income shifting through the loss of shareholder credits under the Australian integration variant or the loss of withholding tax credits under the dividend deduction proposal is not a well targeted policy. It is ineffective in many cases but too harsh in others. These integration proposals were designed to solve the corporate double tax problem, which inevitably involves some new regime for dividends. But that is the source of their flaws in the present context because the distribution of dividends is at the discretion of companies and shareholders. Capital gains are an alternative way of obtaining the full value of retained earnings without the requirement that sufficient corporate level tax be paid.

Furthermore, using integration to discourage inversions requires that foreign investors be denied integration benefits. But that may subvert the initial goal of integration to reduce the cost 
of capital in the corporate sector if foreigners are important investors. Indeed, under the ALI proposal, the tax rate on foreign investors would rise above its current level.

Dividends paid deduction plans are in substance equivalent to the ALI withholding tax, except that companies can claim a permanent reduction in tax on their financial accounts. But, as in the ALI proposal, the company is still responsible for paying the withholding tax. The aftertax return to the shareholder is identical.

\section{E. Withholding Taxes on Interest?}

Proposals for withholding taxes on interest payments are, as in the ALI proposal, frequently linked with integration to equalize the tax on debt and equity. But withholding on interest has several serious problems. There are many domestic and foreign issuers of highly substitutable debt. Imposing a withholding tax on some segments of this integrated market will lead to large portfolio reallocations. The main result will be an increase in funding costs for the sector affected without much reduction in the net interest rate received by investors. Another issue is how withholding applies to financial intermediaries. The gross withholding tax may far exceed the bank's profit spread on the transaction. A separate issue is the treatment of interest (in dollars) received from a foreign payor.

Furthermore, even if the withholding tax on interest is feasible, it may have a negative impact on the U.S. economy through its effect on interest rates. Companies would reduce their supply of debt as they substitute equity for debt and cut back on investment because of increased borrowing costs. This issue was studied by Grubert and Mutti (1994) in the context of the Comprehensive Business Income Tax (CBIT) under which interest payments were not deductible (which is sometimes referred to as backwards integration). Using a CGE model they projected a large decline in the U.S. capital stock of about 5 percent because of the sensitivity of cross- 
border debt flows to interest rate differentials. In summary, interest withholding schemes are difficult to implement, and if they could be made to work they would harm the U.S. economy.

\section{F. The Graetz-Warren Integration Proposal in this Forum}

The Graetz-Warren proposal (Graetz and Warren 2016) largely follows the ALI (Warren 1993) dividend withholding tax scheme, without being specific about the parameters proposed by ALI. Their paper seems to disagree with a capital gains preference but is not explicit whether they are proposing a rate of 39.6 (plus 3.8) percent, the top personal rate, as recommended earlier by Professor Warren. They propose a tax on investment income received by tax exempts and pension funds to offset the revenue loss attributable to the dividend deduction. They do not specify whether that includes capital gains. Similarly, they propose a withholding tax on investment income earned by foreigners but do not mention capital gains and the problems of taxing them. The ALI report was very clear in showing the importance of taxing capital gains because they are a way of receiving corporate income without using up the Taxes Paid Account.

In support of their contention that integration will greatly reduce the incentives for income shifting, Graetz and Warren (2016) cite the paper by Amiram, Bauer, and Frank (2014). These authors evaluated the impact of the elimination of imputation systems by Finland, France, Germany, Italy, and Norway as a result of rulings by the European Court of Justice, as well as the enhancement of imputation credits by Australia in 2002. They find a significant increase in tax avoidance in the European case and the opposite in the Australian case. But the effect seems to be concentrated in largely domestic companies. It is insignificant for multinationals, which is surprising in view of MNCs' opportunities for tax avoidance. Their results may simply reflect accelerated R\&D and depreciation deductions by domestic companies. Furthermore, any observation may not be very relevant for the United States because tax exempts like pension 
funds and 501(c)(3)s are also probably less significant in these countries. For example, pension funds are taxed in Australia and benefit from imputation credits. Furthermore, the authors might have tried to identify the source of any impact more precisely. They do not use information on how close companies were to having their imputation credits limited by the taxes they paid. Another possibility would be to interact the initial level of dividend payouts with the imputation change variable. Low dividend payers would not have been significantly constrained.

Graetz and Warren (2016) recognize the problems of implementing a withholding tax on interest and the large portfolio reshuffling it can induce. However they seem to believe that restricting the deductibility of interest payments will not create these problems. The same tax payment goes to the government so the result would seem to be the same.

\section{TAXING CORPORATE INCOME AT A 15 PERCENT RATE AND DIVIDENDS AND CAPITAL GAINS AS ORDINARY INCOME WITH AN INTEREST CHARGE ON DEFERRED LIABILITIES}

As indicated in the introduction, we examine a proposal to shift the burden of the tax on corporate income to the personal level by lowering the corporate tax rate to 15 percent and taxing dividends and capital gains as ordinary income. In addition, an important aspect of the proposal is to impose an interest charge on the deferred tax liabilities on accruing capital gains when taxpayers realize their gains. This provision is designed to deal with the problems created by a personal tax rate on dividends and capital gains that is much higher than the corporate rate. Without the interest charge, companies would reduce their dividend payouts and shareholders would increase the holding periods for their investments before realizing gains. Evidence on the large effect of tax rates on capital gains realizations is very compelling (Dowd, McClelland, and 
Muthitacharoen, 2015). Controlling shareholders in a closely held corporation would also attempt to recharacterize management income as corporate income taxed at much lower rates.

The higher tax rate and interest charge applies to all capital gains, not just gains from publicly traded shares, and includes assets such as real property, derivatives, carried interest, and collectibles. Unlike the Toder-Viard mark-to-market proposal, this approach does not create a large differential between the tax rate on publicly traded shares and other assets. There is no incentive to shift assets with high expected growth to the non-traded and non-corporate sectors. IPOs will not be delayed to preserve the opportunity for both deferring the tax on capital gains and enjoying the lower tax rate that would continue to apply to nontraded assets.

An interest charge on deferred tax liability has a precedent in the Internal Revenue Code in the form of the PFIC rules in sections 1291-1298. If a shareholder invests in a PFIC and does not elect either to mark to market or be in a Qualified Electing Fund (QEF), which annually reports the ordinary income and capital gains earned by the fund, the gain when the PFIC is liquidated is assumed to have accrued "ratably" over the holding period. The tax liability, at ordinary rates, imputed to each year carries an interest charge until realization. The final tax liability is the sum of the tax imputed in each year plus the cumulative interest charges until realization.

The PFIC rules have some useful mechanics that we incorporate. For example, all interest charges are for full years. We assume that the taxpayer paid the tax in the past on April 15 and that the final liability will be due on the April 15 after the year of the sale. But the interest charge proposal has several significant differences from PFIC, which seems to be a punitive regime designed to induce taxpayers to elect a QEF or the mark-to-market alternative. The PFIC interest regime specifies a "ratable" or constant absolute gain spread over the holding period, while we 
prefer an equal compound rate of return assumption, which is fairer to the taxpayer. PFIC also specifies that the relevant tax applied to yearly gains plus interest is the top marginal rate in that

year. In contrast, the interest charge proposed here just adds the gain plus interest charges to the taxpayer's taxable income in the year of disposition. Also, the PFIC interest charge is the general penalty rate for underpayment of tax liabilities. In contrast, the basic rule for the interest rate in the proposal is to make the shift in the burden of taxation create no greater overall incentives to defer realization, limit dividends, recharacterize wage income as corporate income, or accumulate passive income in a corporation than current law.

The tax liability on the transaction depends on the actual capital gain, the holding period, the interest charges, and the individual's tax rate. It is therefore different from the Auerbach (1991) solution which does not depend on the actual gain, but only on the final sales price, the holding period, and the interest rate. The interest charge is therefore not strictly VickreyAuerbach optimal in maintaining neutrality between realizing a gain and deferring the sale for another period but, as explained above, that is not strictly the goal of our system. Because of fairness or distributional considerations, it is difficult to avoid making the tax liability depend on the actual gain. As we will see, the interest charge on the final gain not only reduces the incentive to defer capital gains realizations, but also to limit dividends, to recharacterize wage income as corporate income, and to accumulate passive income in the corporation.

\section{A. Taxing Gains at Death and Maximum Distribution Rules}

Because the interest charge accumulates as the holding period progresses, two obvious backstop provisions are necessary. One is that there is a deemed capital gains realization at death and the tax liability includes the interest charge accumulated over the holding period. This also applies when appreciated assets are given to another individual. It should not be possible to 
escape the interest charge by continuing to defer realizing gains indefinitely. ${ }^{11}$ A similar proposal without an interest charge was in the Administration’s Fiscal Year 2016 budget (Office of Management and Budget (2015).

It should also not be possible for a corporation to pay a large dividend far in excess of current income to reduce the expected capital gain and associated interest charges just before the shareholder contemplates a sale. There thus has to be a maximum allowable distribution in any period. Anything above the threshold is subject to the interest charge over the holding period. If a dividend does not exceed current earnings it cannot be interpreted as reflecting any deferral of payouts. There is in fact an excess distribution rule under the current PFIC rules - 125 percent of the average amount of dividends received in the previous three years. A limit based on recent profits per share would be conceptually superior but it might be more difficult for the shareholder to obtain that information.

\section{B. A Mark-to-Market Option?}

Taxpayers could elect a mark-to-market option for their publicly traded securities (such as is available now in PFIC). The election presumably would be irrevocable or could only be changed with the permission of the Secretary of the U.S. Treasury. Furthermore, all publicly traded securities the taxpayer holds would have to be included in the election.

Shareholders might make the mark-to-market election if their shares have been relatively flat for a long period of time. They could thereby avoid large interest charges going back over the whole holding period if they experience a large gain in the future. Another possibility would be to make mark-to-market mandatory for publicly traded securities, although it would

\footnotetext{
${ }^{11}$ It would of course be possible to continue accumulating interest charges through the generations but that would create severe compliance problems, such as establishing the initial basis.
} 
exacerbate the line drawing issues referred to above. However, it would simplify the system because the interest charge would apply only to nontraded assets.

\section{Design Issues}

Our interest charge proposal faces a number of design issues.

\section{The Tax Rate}

The tax rate applied to accumulating gains would have to be determined. Possible options include the top marginal rate in each year as in PFIC, the individual's own tax rate in each year, or the individual's final tax rate when the asset is sold. For simplicity, we would choose the taxpayer's final marginal tax rate. As discussed below, this would then make it feasible for the IRS to publish a table each year showing how the markup on the capital gain realized in that year depends on the holding period and the percentage gain over the original basis. The resulting adjusted capital gain could just be added to taxable income subject to the normal schedule.

\section{The Interest Rate}

Under the present PFIC rules, the interest rate used for the interest charge is the U.S. Treasury average short-term rate plus 3 percentage points for individuals and 2 percentage points for corporations, which are the rates for underpayments. The short-term rate is the average yield

on U.S. Treasury securities with a remaining maturity date of less than three years. In contrast to the penalty rate for underpayments under PFIC, the Vickrey-Auerbach theory specifies the interest rate should be the after-tax risk-free rate. As indicated earlier, the interest rate in the current proposal would be chosen to keep holding periods and earnings retention rates no greater than under current law. It should also deter individuals from using corporations to hold passive assets or recharacterize labor income as corporate income. 
There are thus four margins that the interest charge is intended to affect: (1) the capital gains realization decision; (2) the dividend payout decision; (3) the decision to accumulate passive income in a corporation; (4) and the decision to recharacterize wage income as corporate income. (These may be related, e.g., retaining income and investing in passive assets.) Any decision along any margin will be reflected in the final gain at the end of the holding period. The decision to establish a corporation to accumulate passive income is somewhat different from the other three decisions in that it deals with after-personal-tax income. Deferring dividends, deferring realizations, and recharacterizing wage income as corporate income all involve prepersonal-tax income.

The gain from incorporating a "cash box" with after-tax income depends on the difference between personal and corporate tax rates, and would require a lower interest charge. The 15 percent corporate level tax plus the interest charge on deferred liabilities should be at least as great as the tax on the associated passive income if held directly. The common interest charge chosen must therefore be a compromise. It should be designed to prevent any increase in the overall revenue loss from behavioral changes, although there may be gains or losses from specific behaviors. Because deferring dividends and gains realizations are probably the most important margins, they will dominate the interest rate choice.

The choice of interest rate will be based on observed behavior. Existing studies on the response of realizations to changes in tax rates would give an indication of the return from holding versus selling and reinvesting. Similarly, any changes in realizations in response to market interest rates would indicate how the interest charge should be adjusted over time. Shareholders may vary in their responses because of different tastes and positions. The common interest charge would be designed to keep aggregate revenue at the overall "static" target. 
Another question regarding the choice of the interest rate is how it should change if the interest rate varies over the holding period. Should the interest charge be the one that applies for each year or the interest rate in the year of the sale? Using the latter would be the simplest option. If the IRS were to publish a table, it could average the annual interest rates for each holding period for the purpose of imputing the interest charge. It could even apply the relevant interest rate for each year in the holding period.

\section{The Treatment of Losses}

If the taxpayer sells an asset at a loss, it would seem symmetric to apply an interest component to the loss assigned to each year of the holding period. These losses could offset gains with carryovers as in current law. Since gains are taxed as ordinary income, it would be appropriate to relax the limitation on the extent to which capital losses can offset other income.

\section{Ratable Even Gains Versus Equal Compound Rate of Return Over the Holding Period}

Even gains put more of overall gains earlier in the holding period where they get a larger interest charge. For example, consider a 100 percent gain over ten years. In linear even gains, the return imputed to the first year is 10 percent versus 7.2 percent assuming equal annual rates of return.

\section{Deductibility of the Interest Charge}

Some taxpayers have objected to the non-deductibility of the interest charge under PFIC. But as discussed earlier, the interest charge would be chosen to keep the incentive to defer realizations no greater than current law. If the interest charge is deductible that would require a higher interest rate. Under Vickrey-Auerbach theory, the after-tax risk-free return is applied on 
the grounds that it corresponds to the return the taxpayer would have expected to earn if s/he sold the asset and reinvested the proceeds.

\section{Transition}

The treatment of holding periods that begin before the effective must be determined. One clear possibility is to spread the gain over the holding period but only impute interest to the estimated tax liability after the effective date. The gains before the effective date would be subject to the lower pre-effective date tax rate. That would still reduce the incentive to defer realizations compared to present law. Of course this might not be a major problem because taxpayers would try to realize any actual gains before the effective date to have them taxed under the much lower capital gains tax rate.

\section{Compliance Issues}

\section{Taxing Foreign and Domestic Mutual Funds}

In applying the interest charge to accrued gains, the shareholder's holding period is relevant, rather than the fund's holding period. Whether any dividend derives from a capital gain in the fund or from current earnings is irrelevant. If the dividend exceeds the maximum allowable distribution, the excess is subject to the interest charge. If any gain realized by the fund is not distributed to taxpayers, it increases the value of the fund and is eventually subject to the interest charge when liquidated — similar to the mechanics of the PFIC.

\section{Sales and Dividends}

An interest charge applies when a realization occurs under the current rules. For the purposes of the excess dividend provision, a dividend occurs when a payment other than debt repayment reduces the potentially taxable gain in the stock. Thus, selling an option against a long position in an appreciated stock holding is not a dividend because Earnings and Profits are not 
reduced. A sale occurs if the option is exercised. But a transaction that swaps a dividend for an interest payment is obviously a dividend. Accordingly, the provisions on dividend equivalent payments in Section 871(m) would apply. A buyback of stock would be a sale, not a dividend equivalent even if financed with retained earnings because the aggregate gain in the stock is preserved.

\section{E. An Annual Table to Help Taxpayers Apply the Interest Charge}

The interest charge under the current PFIC rules is very complicated. It specifies the top marginal rate in each year of the holding period, which could vary. The applicable interest could vary as well. We would simplify matters by assuming that the individual's tax rate in the year of sale is the relevant one. Also we could assume that the applicable interest rate for the whole holding period is the one announced by the IRS for that year. A simple alternative would be for the IRS to average the interest rates for each holding period. Indeed, the IRS could apply the relevant interest rate to each year in the holding period. Whichever interest rate is chosen, the total liability including the gain and the interest charges would depend on the gain and the holding period. If a "ratable” even gain is implemented, the IRS could annually publish a table showing the percent increase in the gain attributable to the interest charges for any given holding period. The taxpayer would then apply this percentage to the nominal gain and enter the combined amount in taxable income. If the system assumes an equal rate of return over the holding period, it would have to be a two dimensional table showing the percent increase in tax liabilities depending on both the holding period and the percent gain relative to the original basis.

\section{F. Incentives to Defer Sales Compared to Current Law}

Although the proposed scheme is not perfectly Vickrey-Auerbach neutral, the key factor in determining its viability in terms of revenue is whether it creates less of an incentive to defer 
realizing capital gains than exists under current law. At the same tax rate, the interest charge will always reduce the incentive to defer. But the incentive to defer transactions increases with the tax rate, and the proposal contemplates a large increase in the tax rate on dividends and capital gains compared to current law.

Under the proposal, the interest rate would be chosen to assure that the incentive to defer realizing capital gains would be no larger than current law. In order to see where the interest rate might lie, we first simulated the incentive to defer realizations under the Vickrey-Auerbach specifications. The interest rate used is the expected risk-free return. The theory specifies the after-tax interest rate because that is what investors will earn if they sell and reinvest the proceeds. We ran simulations with both the after-tax interest rate and the pre-tax interest rate.

We considered a case in which the tax rates on dividends and capital gains changes from 23.8 percent, the top rate on capital gains and dividends under current law, to 43.4 percent, the top rate on ordinary income under current law. The expected annual (risk-free) increase in the value of the asset is assumed to be 5 percent (after any corporate tax), which is also the level of the interest charge. We also take the least favorable case of a large capital gain at the beginning of the holding period. As Auerbach (1991) notes, the assumption of an even gain over the holding period always creates an incentive to defer realization of a large early gain compared to Vickrey-Auerbach neutrality. However, our simulations indicate that this benefit of deferring realizations generally tends to be lower than under current law even with the large assumed difference in tax rates.

We assume a gain $G$ in the first year and no gain in any subsequent year. After $n$ years the gain attributed to each of the $n$ years is $G / n$ under the simplifying assumption of a "ratable" or even gain. If the tax rate on ordinary income is $t$, the potential tax liability after $n$ years is 
$t(G / n)\left[1+(1+r)+(1+r)^{2}+\ldots+(1+r)^{n-1}\right]=t(G / n)\left[(1+r)^{n}-1\right] / r$. The taxpayer could sell the asset now, incur this liability, and reinvest the net proceeds expecting to earn $r$. Alternatively, s/he could defer selling, expecting to earn $r$ on the pre-tax value $G$, and liquidate after the next period. The tax liability is found by substituting $n+1$ for $n$ in the above expression. In addition, the taxpayer would expect to pay tax equal to $\operatorname{tr} G$ on the additional year's expected earnings. The net difference in the $\boldsymbol{n}+$ lwealth under the two strategies represents the benefits of deferring the sale. This can be compared with the benefit of deferring the transaction under current law with preferential tax rate $T$, namely $G(1+r)(1-T)-G(1-T)[1+r(1-T)]$.

This comparison between the benefits of deferring tax under current law and under the interest charge proposal can be illustrated in a simple example. Suppose a taxpayer earns a capital gain in the first period and is deciding whether to realize the gain or defer selling for one more period. Under current law, realizing the gain $G$ at the end of the first period and reinvesting the proceeds would result in $0.762 G \times(1+0.762 \times 0.05)$ at the end of the second period. If realization is deferred to the end of the second period and the taxpayer expects the asset to increase in value by the same 5 percent, end of second period wealth would be $G(1+0.05)(0.762)$. The gain from deferring the sale is $0.009068 G$. Under the proposal with a tax rate of 43.4 percent, liquidating after the first period and reinvesting the proceeds would result in $0.566 G(1+0.566 \times 0.05)$ at the end of the second period. If the taxpayer chooses to defer selling, the proceeds before the interest charge would be $G(1+0.05)(0.566)$. But in addition the interest charge on the gain has to be paid. The gain is assumed to accrue evenly over the two periods. No interest is due for the second period gain. Therefore the additional tax that has to be paid is $(G / 2) \times 0.434 \times 0.05$. The difference between the two strategies in terms of 
period two wealth is $0.001432 G$, or less than 20 percent of the benefit of deferring under current law.

Even if the interest charged reflects the after-personal-tax risk-free rate, as is indicated by Vickrey and Auerbach, the benefit of deferring realization in the first period is $0.006141 G$, still substantially less than the $0.009068 G$ benefit under current law. This indicates that charging interest rates consistent with Vickrey-Auerbach optimality achieves the goal of reducing the incentive to defer realization below current law even though the tax rate is much higher.

The series is slightly more complicated if an equal annual rate of return is assumed. The annual return becomes $\log (1+G) / n=A$, assuming continuous compounding. The most distant year in the holding period is assumed to earn $B \times A$ where $B$ is the original basis. The tax liability for that year is therefore $t B \times A \times(1+r)^{n-1}$. The next year's liability is $t B \times A \times(1+A) \times(1+r)^{n-2}$, where the annual return is now higher because it compounds the first period gain.

We can illustrate the difference between the operation of an equal annual rate of return assumption and an even absolute gain using the same two-period example above. The taxpayer has a 20 percent gain in the first period and no further gains thereafter. All of the other assumptions are the same as above. Thus, the taxpayer's end of first period wealth is $1.2 \times B$. Under current law, the expected benefit of deferring realization is $0.009068 \times 0.2 \times B$, the same as earlier. Under the proposal, the expected wealth from selling after the first period and reinvesting the proceeds is $0.566 \times 0.2 \times B(1+0.566 \times 0.05)$, again the same as before. The only change in the benefit from deferring realization is that the annual gain $G / 2$ is replaced by 0.0955 , the annual rate of return that compounds to a 20 percent return after two years. That is, the additional tax that has to be paid is $0.0955 B \times 0.434 \times 0.05$. Substituting for $G=0.2 B$, we 
can see that the benefit of deferring under the interest charge proposal is now $0.00192 G$, somewhat higher than before but still much lower than the benefit under current law.

A similar comparison of incentives would apply to dividend payout decisions. Companies would presumably respond to the preferences of shareholders. A given amount of aftercorporate-tax earnings $E$ in a given year is the equivalent of the gain $G$ above. It can be retained, increasing the value of the company by $E$, or paid out as a taxable dividend to the shareholder. After paying the personal level tax, the taxpayer reinvests the net proceeds and expects to earn a before-personal-level tax of $r$. Conversely, if the company retains $E$ it can defer the shareholder's level tax. It expects to earn an after corporate tax return of $r$ on $E$. The taxpayer sells the shares after the second period and pays the capital gains rate. The two strategies are compared as above to evaluate the benefits of deferring the payout of the dividend. The difference between current law and the proposal is the much higher personal tax rates on dividends and capital gains and the interest charge on the deferred gain under the proposal. The analysis is parallel to the capital gains realization decision.

\section{G. Incentives for Income Shifting}

The reduction of the corporate tax rate from 35 percent will greatly reduce the benefits of income shifting. The 15 percent rate would also limit the gains from inversion or expatriation, such as opportunities to strip interest and to move present and future foreign income out of the U.S. tax net. An offsetting factor is any increase in the tax on foreign income in the form of a minimum tax on foreign income. However the revenue cost of an overall minimum tax would be relatively modest. Grubert and Altshuler (2013) reported that an overall 15 percent minimum tax would, on a static basis, amount to a 2 percentage point tax on total foreign income, less than the companies would gain from being able to repatriate tax free. 


\section{H. The Tax Treatment of Foreign Income}

Lowering the U.S. corporate tax rate to 15 percent will have a very significant effect on reducing base erosion. The question is how active foreign income earned by U.S. MNCs should be treated. The basic alternatives are simple dividend exemption, dividend exemption with expense allocations to exempt income, a per country minimum tax at 15 percent, and an overall foreign minimum tax at 15 percent. In each case, passive income, interest, and royalties received would be fully taxed at 15 percent. The overall minimum tax is much simpler than the percountry minimum because it avoids all the complications of assigning a component of foreign income to its tax residence. (As explained in Grubert and Altshuler (2013), taxing the income on the basis of where the CFC is incorporated is easily avoided by the various ways companies can separate the tax residence of income from the place of incorporation.) Furthermore, the overall minimum tax shares many of the advantages of the per country system. Grubert and Altshuler (2013) found that under a 15 percent overall minimum tax, companies that account for two-thirds of MNC foreign income would be subject to a marginal tax rate of 15 percent. The reaction of those companies would be similar to their reaction to a per-country minimum tax. The remaining third would have enough excess foreign tax credits to shield additional low tax income.

\section{Revenue}

Is a 15 percent corporate tax rate feasible? The revenue considerations here are not intended to yield precise revenue estimates, but to indicate that a 15 percent rate is not an unrealistic goal. The rough estimates at 2012 levels we refer to below are for the longer run after full behavioral responses.

In 2012, corporate tax revenues amounted to $\$ 320$ billion. We contemplate some modest base broadening so the tax base to which the 15 percent rate applies would be somewhat larger. 
If we assume a modest 10 percent increase in the tax base, which would finance a reduction of the tax rate from 35 to about 31.8 percent, revenue neutrality with a reduction of the corporate rate to 15 percent requires about $\$ 170$ billion at 2012 levels. We use 2012 because the breakdown of the revenue from various components of income is available for that year. The maximum tax rate on capital gains and dividends has risen since then and we use the current approximately 20 percentage point differential compared to ordinary income in the estimates below. The offsets to the loss in corporate level revenues include the following.

\section{Revenues from the Much Higher Tax Rate on Capital Gains and Dividends in}

\section{Addition to the Interest Charges}

Because of the interest charge, we assume conservatively that the holding periods are the same as under current law. The taxes paid on gains eligible for the long-term tax rate averaged $\$ 70.1$ billion per year from 2003 to 2012. The maximum long-term tax rate was 15 percent over this period. ${ }^{12}$ This 10-year period covered both strong and weak stock markets. Taxing these gains at ordinary rates would raise about an additional $\$ 90$ billion. ${ }^{13}$ In addition, rough calculations based on 2009 holding periods suggest that interest charges will increase taxes paid by about 20 percent. $^{14}$

Revenue derived from qualified dividends amounted to $\$ 26.4$ billion in 2012. The average marginal effective tax rate on these dividends was 14.1 percent. The average marginal tax rate on non-qualified dividends was 24.3 percent. If the 10-percentage point differential between qualified dividends and non-qualified dividends persists at the new higher rates and

\footnotetext{
${ }^{12}$ From 2003 to 2009, these computations included the impact of the phase-outs of itemized deductions.

${ }^{13}$ The top marginal rate on capital gains and dividends is now 23.8 percent, including the 3.8 percent on net investment income. Actual collections are only available through 2012 but it might be appropriate to net the estimated gain from the new higher rate.

${ }^{14}$ The latest year for which holding periods are available is 2009. We assumed an interest charge of 5 percent.
} 
qualified dividends were just taxed at the non-qualified rate, it would mean an additional \$20 billion of tax revenue.

2. Revenues from Interest Charges from the Deemed Realization at Death or When Appreciated Property is Transferred to Another Individual

A similar proposal, without the interest charge, was in the Administration's fiscal 2016 budget (Office of Management and Budget, 2015). The estimated gain in FY 2018 assuming a top capital gains rate of 24.2 percent was $\$ 17.5$ billion. (The estimates for 2019 and 2020 were $\$ 15.0$ and $\$ 13.9$ billion, respectively.) At a top ordinary tax rate of 43.4 percent and interest charges for the imputed yearly gains, the annual revenue gain would be a least $\$ 25$ billion at 2012 levels. (The budget proposal provided for a \$100,000 exclusion that could roll over to a surviving spouse, as well as exemptions and extended payments for small business.)

\section{Revenues from the Reduction in Income Shifting from the United States}

Grubert (2012) estimated that 12 percent of U.S. MNCs’ worldwide income in 2004 had been shifted abroad as a result of the differential between the U.S. corporate tax and the average effective tax rate of 15 percent on U.S. MNC income abroad. The tax differential is probably greater now. Furthermore, Hodge (2011) found that the foreign share of national profits increased from 26.3 percent in 2004 to 38.2 percent in 2009. Even if moving to a 15 percent U.S. corporate tax rate reduced income shifting by only one half, that would increase the U.S. corporate tax base by about 7 percentage points. If this is taxed at 15 percent, the gain would be about $\$ 10$ billion per year. Not included in this rough estimate is the reduced income shifting by foreign controlled corporations in the United States. 
The revenues from these items total about $\$ 165$ billion, which is very close to our $\$ 170$ billion target. The following items, for which we do not attempt even rough estimates, should result in a revenue gain beyond the amount needed.

\section{Increased Investment in the United States.}

Lowering the corporate tax rate to 15 percent would increase investment in the United States by both foreign and domestic investors. U.S. portfolio investors would find domestic stocks relatively more attractive compared to foreign shares. The personal level tax would rise on both equally. The lower corporate level effective tax rate would attract both more portfolio and direct investment from abroad. Finally, the lower corporate rate may cause U.S. MNCs to allocate a greater share of their worldwide investment to the United States. The increased corporate capital in the United States would not only increase corporate level revenues, but would also increase revenues from U.S. domestic labor that becomes more productive with a larger capital stock.

\section{The Taxation of Foreign Income.}

A per country minimum tax at 15 percent would raise substantial revenue. It would also eliminate any incentives for companies based in the United States to shift income. However, it would offset some of the positive effect of the 15 percent domestic tax in reducing expatriations and shifting. The Administration's Fiscal Year 2016 budget, in the Reserve for Business Tax Reform, contained a proposal for a 19 percent per country minimum tax. It was estimated to raise about \$20 billion per year. A 15 percent minimum tax would raise a disproportionately lower amount because of the credits for foreign tax, perhaps $\$ 10$ billion per year. (This does not double count the reduction in income shifting referred to above.) 
A 15 percent overall minimum tax on foreign income would raise much less and would be close to being revenue neutral. Grubert and Altshuler (2013) report that the estimated static gain from the 15 percent overall minimum tax would equal the gain from a 10 percent per country tax.

\section{One-Time Gain in Stock Prices}

These revenue considerations do not include the one-time gain in stock prices resulting from the large reduction in the corporate tax rate. Also, we assume that foreign income would be taxed under some type of dividend exemption system. We do not here include the one-time tax on earnings retained abroad by U.S. corporations prior to the effective date.

\section{Increasing Progressivity of the Personal Tax}

Finally, in the unlikely possibility that there is still a revenue gap, one possibility for raising further revenue is to increase the progressivity of the personal tax. The Administration's Fiscal Year 2016 budget proposed to limit the value of various personal deductions to 28 percent, which would increase taxable income in the higher brackets. The increase in revenue over the 10-year budget window was estimated to be in excess of $\$ 50$ billion per year.

This discussion of revenue sources implicitly refers to the long run. However, any revenue gain in the short run is not likely to be large and may be more than offset in the short run by increased realizations before the effective date. These realizations would of course reduce the present value of revenues, but would smooth out any short run shortfall. Our proposed transition rule for holding periods that started before the effective date is to compute annual gains over the whole holding period, the normal rule, but only impose the interest charge and higher tax rate on the imputed gains after the effective date. The same rule would apply to the deemed realization at death. 
Because of the interest charge after the effective date, the objective of keeping the incentive to defer realizations no larger than under current law, even at the much higher tax rate, would be satisfied. The only difference from the long run revenue estimate is the lower tax rate and absence of interest charges for the period before the effective date. Conversely, shareholders that had assets with very large gains before the effective date would have an incentive to sell before the effective date to avoid having some of their large gains being imputed to the period after the effective date with its interest charges and high tax rates. Moreover, taxpayers who had planned to liquidate their holdings shortly after the effective date would obviously accelerate their realizations. These accelerated realizations before the effective date may make up for any short run loss because of lower interest charges. ${ }^{15}$

Summing up, replacing the corporate level revenue loss from lowering the corporate tax rate to 15 percent seems within reach. Compared to the mark-to-market proposal, our proposal picks up more revenue in present value from dividends and capital gains because gains from non-traded assets are taxed at ordinary rates and corporate revenue is only cut by about half.

\section{J. Distributional Effects}

In assessing the distributional impact of the interest charge proposal, it is useful to consider the effect of the remaining 15 percent of the corporate tax separately from the share of the tax on corporate income that is shifted to the personal level. The incidence of the remaining 15 percent corporate tax will fall on domestic capital owners to a greater extent than the current corporate tax. One of the ways that the corporate tax falls on labor is through portfolio and direct capital flows abroad to escape the tax. However, under the interest charge proposal, any flow of U.S. owned capital to lower tax locations will in part be offset by the current (in present value)

\footnotetext{
${ }^{15}$ Toder and Viard (2014) would spread the pre-effective date gain over a 10-year period and charge the preeffective date low tax rate.
} 
taxation at the personal level of the increase in stock prices resulting from the lower tax burden abroad.

More importantly, several factors cause the shift in the taxation of corporate income to the personal level to have an incidence more progressive than the corporate level taxation that it replaces. For example, the increase in tax on capital gains and dividends applies to resident holdings of both foreign and domestic shares, and cannot be avoided by shifting to foreign stocks.

Furthermore, the increase in tax is exclusively on domestic taxpayers. The increased tax on the corporate income earned by U.S. individual taxpayers has no effect on foreign investors, who get a tax cut and will increase portfolio and direct investment. The pre-tax rate of return earned by resident investors in the corporate sector will decline. (In part this will be a revenue transfer to foreign investors, but it is also in part a transfer to domestic labor.) If the optimal tax on foreign investment is substantially below current levels, the latter effect will dominate. For example, if the supply of foreign capital is perfectly elastic, the standard result is that the optimal tax on foreign capital is zero. If the initial tax on foreign capital is lowered to zero, capital flows in, but foreign investors get the same after-tax return as they did previously. Domestic investors may lose, and domestic labor gets the entire benefit of the inflow including any loss suffered by domestic capital.

The different losers and gainers in the shift in tax from the corporate level to the personal level also suggest an increase in progressivity. For example, pension funds gain from the lower corporate tax rate, and pension income is more equally distributed than individual capital gains and dividends. The beneficiaries of charitable and educational institutions that benefit from the corporate rate cut are also likely to be lower and middle income households. 
Also, even within the group of taxable individuals, the shift of the uniform incidence of the corporate tax on all shareholders irrespective of income to the progressive tax schedule for capital gains and dividends will have a similar progressive distributional effect.

The evidence and existing distributional analysis by U.S. Treasury and others support a progressive effect for the reform (Altshuler, Harris, and Toder, 2010). In 2012, 73 percent of the revenue from long-term capital gains was earned by taxpayers with Adjusted Gross Income greater the $\$ 1.0$ million, 82 percent with AGI above $\$ 500,000$, and 93 percent with AGI above $\$ 200,000$. Similarly, 52 percent of qualified dividends were received by taxpayers with AGI above $\$ 1$ million.

The U.S. Treasury distribution model for 2016 income levels and law finds that 72.5 percent of the burden of the corporate income tax is borne by the top decile. In contrast, 90.7 percent of the tax on qualified dividends and positive long-term capital gains is borne by the top decile. This pattern is even more notable in the top 1 percent, which is estimated to bear 49 percent of the corporate income tax but 73.7 percent of the taxes paid on qualified dividends and positive long-term capital gains. ${ }^{16}$

The proposal in the Administration's Fiscal Year 2016 budget to tax capital gains at death is even more skewed to the top of the income distribution. The U.S. Treasury estimates that more than 80 percent of the tax would be paid by the top 0.1 percent — those with income greater than $\$ 2$ million. ${ }^{17}$

\section{K. Comparison of Interest Charge Proposal with 15 Percent Per Country Minimum Tax on Foreign Income}

\footnotetext{
${ }^{16}$ See Cronin et al. (2013) for a detailed description of the U.S. Treasury distributional model.

${ }^{17}$ This estimate includes the impact of a proposal to raise the maximum capital gains rate to 24.2 percent, but more than 85 percent of the revenue was accounted for by taxation of gains at death. The proposal has a $\$ 100,000$ per person exclusion which can roll over to the surviving spouse. Furthermore, the tax is not triggered until the death of the second spouse.
} 
Recently we analyzed a per country minimum tax for foreign income (Grubert and Altshuler, 2013). To discourage income shifting from the United States and the resulting distortion of investment, the excess returns in each foreign jurisdiction would be subject to a 15 percent minimum tax net of any local taxes paid. Taxes paid are matched with the tax residence of the income, not necessarily the country in which the subsidiary is incorporated. For example, the income of a CFC incorporated in Ireland with a tax residence in Bermuda under the Irish place of management rules would be assigned to Bermuda. Furthermore, in order to tax only excess returns abroad, investment in tangible assets could be deducted from the minimum tax base. $^{18}$

Apart from greater simplicity, the interest charge proposal differs from the per country minimum tax in several significant ways. First, an increase in the tax rate for U.S. companies in a low tax country represents an increase relative to both the United States and relative to higher tax foreign countries, those with corporate rates above 15 percent. Income and investment will shift both back to the United States and to other foreign countries. Under the interest charge proposal with its 15 percent corporate tax rate, the U.S. tax rate falls relative to all foreign countries, both high tax and low tax.

Probably more important is the contrasting impact of the two proposals on the incentives for U.S. companies to expatriate. The minimum tax constitutes a significant increase in the tax on U.S. MNCs, offset only in part by being paired with tax-free dividend repatriations. It creates an incentive for U.S. companies to expatriate to avoid the minimum tax. In contrast, lowering the U.S. corporate tax rate to 15 percent under the interest charge proposal erodes many of the

\footnotetext{
${ }^{18}$ This is similar to the notional allowance for company assets in the Business Enterprise Income Tax (BEIT) proposed by Kleinbard (2007).
} 
benefits of changing corporate residence. In particular, stripping income out of the United States is much less profitable.

The substantially lower corporate tax rate in the interest charge proposal also has an impact beyond U.S.-based MNCs. Foreign-based companies and foreign portfolio investors will have a greater incentive to invest in the United States. U.S. portfolio investors will have less reason to invest in foreign securities to escape the high U.S. corporate tax.

\section{The Corporate-Noncorporate Distortion}

Although international issues and the distributional effects of the proposals are the main focus of this paper, the impact on the classic corporate-noncorporate distortion is also of interest. Foreign direct and portfolio investors will increase their investment in the U.S. corporate sector because their corporate level tax would fall substantially under the interest charge proposal but they would not be subject to the increase in taxes at the personal level; they do not generally invest in the U.S. noncorporate sector. In a revenue neutral proposal, U.S. resident investors may experience an increased combined tax burden on corporate investment. But several factors suggest there will be a lower overall net tax burden on the U.S. corporate sector. For example, there will be a much higher tax rate on noncorporate capital gains. Also, the personal level tax on portfolio investment abroad will increase. In addition, the additional revenue from less income shifting and fewer expatriations does not represent an additional tax burden. In fact it indicates a net gain to corporations because the saving in shifting costs exceeds the tax they pay on their additional U.S. taxable income.

\section{Comparing Halperin's Proposed Response to the Problem of Lower Corporate Rates}


Halperin (2009) also addressed the issues raised by a shift in the burden of taxation from the personal to the shareholder level. One of his proposals is to deny the lower corporate rate to passive and service income to discourage the accumulation of income in the corporation. For passive income, this would seem to apply the definition already in the Internal Revenue Code, such as in the characterization of Foreign Personal Holding Company Income, to all corporations. These rules already deal with issues such as the allocation of expenses like interest to passive income. The Active Finance Exception to the subpart F rules could also be used for financial institutions. Needless to say these rules are complicated, as would be the definition of services. Halperin also proposes to reduce the step-up in basis at death and the deduction for charitable contributions by the amount of undistributed earnings. Finally, he suggests that the combined corporate and individual rates on corporate distributions should be higher than the top individual rate.

Our interest charge proposal under which the interest rate is chosen to deter the use of corporations to accumulate passive income would seem to be much simpler and more inclusive than the Halperin (2009) alternative. Defining passive and service income would be unnecessary. Deemed realization including interest charges at death renders the step-up problem moot. The interest charge regime also fulfills Halperin's requirement that the combined corporate and individual taxes on corporate distributions be higher than the top marginal rate. In any case, taxpayers may find it difficult to determine what share of earnings was retained during their holding periods, which would require adopting the per shareholder determination of income rules that now apply to Master Limited Partnerships (MLPs). While the specific rules for calculating the interest rate must still be determined, it appears feasible to construct an interest rate regime 
that does not increase the incentive to defer realizing capital gains, reduce dividend payouts, and use corporations to accumulate passive income compared to current law.

\section{N. Final Remarks}

Our interest charge proposal includes full taxation of capital gains and dividends at ordinary rates, the deemed realization of gains at death, and an overall or per country 15 percent minimum tax on foreign income. Each of these tax parameters could be varied somewhat to achieve revenue neutrality. For example, deemed realization at death could have a substantial exclusion, as recommended in the administration's budget proposal. The minimum tax on foreign income could be lower than 15 percent and the tax on capital gains could have a modest preferential feature. More important, the proposal could include a lowering of the individual tax rate schedule through significant base broadening on the personal side of the income tax. That would reduce the required increase in the tax on capital gains and dividends while preserving revenue neutrality. For example, the Simplified Income Tax Plan option in the 2005 Report of the President's Advisory Panel for Federal Tax Reform (President's Advisory Panel, 2005) projected a top individual tax rate of 33 percent.

\section{CONCLUSION}

Our examination of the three alternative methods for shifting the tax burden on corporate income from the corporate level to the personal level indicates that our plan, which lowers the corporate rate to 15 percent, taxes capital gains and dividends as ordinary income, and imposes an interest charge on the tax deferred over the holding period, is highly effective in reducing the benefits of income shifting and expatriation while avoiding some of the major weaknesses of the other options. The proposal can be implemented rather simply and could include a lowering 
of the individual tax rate schedule through significant base broadening on the personal side of the income tax.

The mark-to-market proposal that eliminates the corporate tax entirely is highly effective in reducing income shifting and inversions. However it creates a large tax differential between the tax on publicly traded versus non-publicly traded financial assets, as the latter retain deferral of capital gains and also enjoy the current law low rates when gains are realized. This feature will greatly distort firm decisions regarding whether to be publicly traded, including decisions such as whether a company should engage in an IPO. Line drawing defining what is publicly traded will be complicated. The elimination of the corporate tax makes it difficult to satisfy revenue neutrality. ${ }^{19}$

The integration proposals that either limit shareholder credits to U.S. taxes paid, as in the Australian model, or convert the corporate tax into a withholding tax, as in the ALI plan, have to confront the fact that less than half of U.S. corporate income is owned in currently taxable personal accounts. Thus a large pool of owners will continue to be able to enjoy the benefits of inversions and shifting. In addition, half of U.S. MNCs currently pay enough U.S. tax to be able to give shareholders full credits, and can thus continue to shift income to low-tax locations. Furthermore, even the companies without enough potential credits and their shareholders can respond to weaken the intent of the proposal. For example, companies can reduce their dividends, letting shareholders eventually obtain their returns in the form of lightly taxed capital gains. There could also be major clientele effects in which companies without enough credits are held in exempt accounts. Companies with low payout rates would continue to be inversion candidates.

\footnotetext{
${ }^{19}$ Toder and Viard (2016) have revised their proposal to include a 15 percent corporate tax, shareholder integration, and a tax on interest received by pension funds and tax exempts. Shareholder integration brings problems of its own.
} 
To be sure, numerous design issues must still be resolved under our proposal. The determination of the interest rate is one example. However it appears that a straightforward approach can be developed that achieves the objective of preventing large behavioral responses such as an increase in deferred realizations. 


\section{REFERENCES}

Altshuler, Rosanne, Benjamin Harris, and Eric Toder, 2010. "Capital Income Taxation and Progressivity in a Global Economy.” Virginia Tax Review 30 (2) 1145-1184.

Amiram, Dan, Andrew Bauer, and Mary Margaret Frank, 2014. “Tax Avoidance at Public Companies Driven by Shareholder Demand: Evidence from Changes in Shareholder Dividend Tax Policy.” Darden Business School Working Paper No. 2111467. University of Virginia, Charlottesville, VA.

Auerbach, Alan J., 1991. "Retrospective Capital Gains Taxation.” American Economic Review 81 (1), 167-178.

Auerbach, Alan J., 2006. "Who Bears the Corporate Tax? A Review of What We Know." In Poterba, James (ed.), Tax Policy and the Economy, Volume 20, 1-40. MIT Press, Cambridge, MA.

Cronin, Julie Anne, Emily Y. Lin, Laura Power, and Michael Cooper, 2013. "Distributing the Corporate Income Tax: Revised U.S. Treasury Methodology.” National Tax Journal 66 (1), 239262.

Dowd, Timothy, Robert McClelland, and Athiphat Muthitacharoen, 2015. "New Evidence on the Tax Elasticity of Capital Gains.” National Tax Journal 68 (3), 511-544.

Graetz, Michael J., 2014. "The Bipartisan 'Inversion' Evasion: Neither the White House nor Congress Seems Interested in Tax Reform That Would Make Companies Want to Stay Here.” Wall Street Journal, September 25, http://www.wsj.com/articles/michael-j-graetz-the-bipartisaninversion-evasion-1411687141.

Graetz, Michael J., and Alvin C. Warren Jr., 2014. “Unlocking Business Tax Reform.” Tax Notes, (November 10), 707 -712.

Graetz, Michael J., and Alvin C. Warren Jr., 2016. "Integration of Corporate and Shareholder Taxes.” National Tax Journal 69 (3), xxx-xxx.

Gravelle, Jane G., and Donald J. Marples, 2015. The Effect of Base-Broadening Measures on Labor Supply and Investment: Considerations for Tax Reform. CRS Report R44242. Congressional Research Service, Washington, DC.

Grubert, Harry, 2012. "Foreign Taxes and the Growing Share of Multinational Company Income Abroad: Profits, Not Sales, Are Being Globalized.” National Tax Journal 65 (2), 247-282.

Grubert, Harry, and Rosanne Altshuler, 2013. "Fixing the System: An Analysis of Alternative Proposals for the Reform of International Tax.” National Tax Journal 66 (4), 671-712.

Grubert, Harry, and John Mutti, 1994. "International Aspects of Corporate Tax Integration: The Contrasting Role of Debt and Equity Flows.” National Tax Journal 47 (1), 111-133. 
Halperin, Daniel, 2009. “Mitigating the Potential Inequity of Reducing Corporate Rates.” TPC Working Paper. Urban-Brookings Tax Policy Center, Washington, DC.

Hobbs, James R., 2015. “Foreign-Controlled Domestic Corporations, 2012.” Statistics of Income Bulletin (Summer), 1-29.

Hodge, Andrew W., 2011. “Comparing NIPA Profits with S\&P 500 Profits.” Survey of Current Business 91 (3), 22-27.

Kleinbard, Edward D., 2007. “Rehabilitating the Business Income Tax.” Discussion Paper 200709. The Hamilton Project at the Brookings Institution, Washington, DC.

Office of Management and Budget, 2015. "Budget of the United States Government, Fiscal Year 2016.” Office of Management and Budget, Washington, DC.

President's Advisory Panel on Federal Tax Reform, 2005. Simple, Fair, and Pro-Growth: Proposals to Fix America's Tax System. U.S. Government Printing Office, Washington, D.C.

Rosenthal, Steven M. and Lydia S. Austin, 2016. "The Dwindling Taxable Share of U.S. Corporate Stock.” Tax Notes 151 (7), 923-934. May 16.

Toder, Eric, and Alan Viard, 2014. "Major Surgery Needed: A Call for Structural Reform of the U.S. Corporate Income Tax.” TPC Research Report. Urban-Brookings Tax Policy Center, Washington, DC.

Toder, Eric, and Alan Viard, 2016. "Replacing Corporate Tax Revenues with a Mark to Market Tax on Shareholder Income.” National Tax Journal 69 (3), xxx-xxx.

Vickrey, William, 1939. “Averaging Income for Income Tax Purposes.” Journal of Political Economy 47 (3), 379-397.

Warren, Alvin C., 1993. Federal Income Tax Project: Integration of Individual and Corporate Income Taxes: Reporter's Study of Corporate Tax Integration. American Law Institute, Philadelphia, PA. 